\title{
Gay Fiction, Homophobia and Post-Troubles Northern Ireland: An Interview with Jarlath Gregory
}

\author{
José Carregal-Romero \\ University of Vigo, Spain
}

Copyright (c) 2019 by José Carregal-Romero. This text may be archived and redistributed both in electronic form and in hard copy, provided that the author and journal are properly cited and no fee is charged for access.

\begin{abstract}
Northern Irish writer Jarlath Gregory became a fresh voice in Irish gay writing when Snapshots came out in 2001, a novel which explores gay experience in Crossmaglen - a Catholic town in Co. Armagh - against the backdrop of the Troubles. Since then, he has published two other novels: G.A.A.Y.: One Hundred Ways to Love a Beautiful Loser (2005), which depicts gay life in 1990s Dublin, and The Organised Criminal (2015), where he offers valuable insights into the Northern Irish underworld of smuggling and cross-border criminality. The present interview, while aiming to fill the gap in criticism on Gregory's brilliant novels, provides a series of reflections on gay fiction, homophobia and post-Troubles Northern Ireland.
\end{abstract}

Key Words. Gay fiction, homophobia, Jarlath Gregory, Northern Ireland, contemporary Irish literature

Resumen. El escritor norirlandés Jarlath Gregory emergió como una voz literaria novedosa cuando, en el año 2001, publicó Snapshots, donde relata cómo es vivir como homosexual en Crossmaglen - un pueblo católico en el condado de Armagh, Irlanda del Norte - con el conflicto de los "Troubles" como trasfondo. Gregory ha publicado otras dos novelas: G.A.A.Y.: One Hundred Ways to Love a Beautiful Loser (2005), que describe la vida gay en el Dublín de los años noventa, The Organised Criminal (2015), que trata sobre el contrabando y el crimen organizado en la frontera norirlandesa. A pesar de que sus obras ofrecen visiones muy interesantes sobre la sociedad irlandesa, la crítica que se ha escrito sobre sus novelas es todavía escasa. Los temas a tratar en esta entrevista son la ficción gay, la homofobia y la "post-Troubles" Irlanda del Norte.

Palabras clave. Literatura gay, homofobia, Jarlath Gregory, Irlanda del Norte, literatura contemporánea irlandesa 
Jarlath Gregory was born in 1978 in Crossmaglen, Co. Armagh, Northern Ireland. He settled in Belfast before moving to Dublin to study Sociology at Trinity College Dublin, and has remained in the Irish capital since then. Gregory became a fresh voice in Irish writing when Snapshots came out in 2001, a time when "there were few, if any, gay voices in Ulster fiction" (Bradley 18). Snapshots explores gay experience in Crossmaglen, against the backdrop of the Troubles. His second novel, G.A.A.Y.: One Hundred Ways to Love a Beautiful Loser (2005), portrays the newly gained sexual freedoms for young gay men in a more liberal Dublin. An early reviewer rightly notes that "G.A.A.Y. is modern, earthy, graphic and hilarious. It's also stunningly written, and shows a side of Dublin the straight world never sees" (Leonard 95). His third novel, The Organised Criminal (2015), tackles smuggling business and organised crime on the Northern Irish border. Gregory's latest novel has been regarded as "post-Troubles" fiction (Savage, 2015), as it deals with the legacies of the Troubles in a still isolated, introverted Northern Irish world, affected by longstanding sectarian rivalries. Gregory himself explained that he "was inspired by the inherent drama to life in Northern Ireland, and was keen to explore afresh the underlying social issues prevalent in the community" (Savage). Despite the originality of Gregory's insights into Irish life, there is a startling paucity of criticism on his work.

I discovered Gregory's novels while doing research on lesbian and gay writing in contemporary Ireland. ${ }^{1}$ This interview took place in October 2017 during my research stay at University College Dublin. This interview, while aiming to fill the gap in criticism on Gregory's brilliant novels, provides a series of reflections on homophobia, gay fiction and "post-Troubles" Northern Ireland.

José Carregal-Romero: Hi, Jarlath. First of all, I would like to thank you for accepting my invitation for an interview. I am currently working on the lesbian and gay fiction of contemporary Ireland, North and South. Do you have any favourite gay/lesbian novels?

Jarlath Gregory: One of my favourites is The Swimming Pool Library (1988) by the British writer Alan Hollinghurst. It recreates the clandestine nature of gay sex in 1980s Britain, as well as issues of social class and race. I also remember reading Jamie O'Neill's At Swim Two Boys - which came out in 2001, only a month after my first novel, Snapshots - and being fascinated by the way O'Neill explored Irish history. It's a rich, long and brilliant novel, with a beautiful gay love story at the heart of it. I think it is my favourite.

JCR: And I would also add that At Swim, Two Boys is one of the most popular and influential gay novels in Ireland. A great number of historical novels were published after O'Neill's work, some of them dealing with gay/lesbian issues. I am thinking, for example, of Colm Tóibín's The Master (2004), Emma Donoghue's Life Mask (2004) and The Sealed Letter (2008); John Boyne's The Absolutist (2011) and The Heart's Invisible Furies (2017), and Sebastian Barry's Days Without End (2016).

JG: It's difficult for literature in general to identify with the present moment, and that's why a lot of writers turn to historical fiction. With fiction, you are always trying to reinterpret the past and give a human context to events that happened in society at a given moment. However, as a fiction writer, I am mostly interested in contemporary life; life as it is lived now. Particularly with G.A.A.Y., I was conscious of trying to capture a time and a place that was very 1990s. This was the time when on-line dating was starting to happen. My intention was to write about a teenager who was growing up in the middle of all that, who was a very identifiable type; the young gay man who, probably, has some universal characteristics, but 
who was also very specifically rooted in Dublin life. At the time I was writing Snapshots and G.A.A.Y., I also felt that many of the acceptable mainstream stories about gay life tended to be the "coming out" story. The "coming out" issue is only marginal in my novels; my intention was to catch up with the lived gay experience behind that.

JCR: I am interested in how Ireland passed from being one of the most homophobic countries in the Western world in the 1990s and early 2000s (see Ferriter 509) to being the first one to legalise same-sex marriage by popular vote in 2015 . You are Northern Irish, but staunch homophobia has also been pervasive in the society you grew up. In recent years, the increased visibility of homosexuals favoured the implementation of new civil rights for gays and lesbians. Nevertheless, in Ireland, homophobic bullying continues to be endemic in primary and secondary school environments, as some studies indicate (see O'Higgins-Norman; Mannix-McNamara et al.; Bird 15). Would you say that young LGBT people in Ireland and Northern Ireland enjoy a much greater sense of freedom today, compared to the years when you grew up as a gay man?

JG: Overt homophobia is not tolerated, it's not "cool", but still persists. So, no doubt, younger people who are growing up LGBT still face a certain level of oppression. But, today, it is easier for LGBT teenagers to find other people like them or, at the very least, sympathetic towards them. They would probably know of someone else who is openly gay or lesbian, which was not necessarily the case in the 1990s. The LGBT youth today is not as isolated as it used to be in the past, and this is tremendously important. Cultural referents have also become more abundant; you have singers and actors who are out, and the mainstream media provides depictions of LGBT life. But, at the same time, there can be problems regarding the stereotyping of queer identities in the mainstream media. LGBT adolescents should be able to get information and support from sources other than the media or the Internet.

JCR: I read a study which found that around $62 \%$ of same-sex attracted 16 year-olds in Northern Ireland intend to leave the country as adults (see Schubotz and O'Hara 501).

JG: Only 62 percent!?

JCR: Well, you left in the 1990s, and this study was conducted in the 2000s. I realised that, as a university student, you moved to Dublin and remained there since then. And I also noticed that in G.A.A.Y. you portray a much more open universe in Dublin than you do when you write about Crossmaglen in Snapshots. Had your sexuality anything to do with your decision to stay in Dublin?

JG: Yes, definitely. Northern Ireland is a very insular place. It is a very religious society, and one of the most homophobic and hostile environments in Europe - only comparable to Poland, I would say. When I moved to Dublin in the 1990s, it felt much more open, more accepting. It was an easier place to be openly gay. People of my age living in Northern Ireland were not openly gay at the time, probably because of all the cultural issues around politics and religious identity there.

JCR: In your latest novel, The Organised Criminal, there is a short scene where Jay O'Reilly - who lives in Dublin but returns to Crossmaglen for a family funeral - listens to the radio, and he hears listeners phoning in and airing "their grievances about marriage equality" (33). Then, he says: "I hadn't heard the local news in three years, but nothing had changed" (34). This scene reminded me of a radio interview given by 
the Unionist politician Iris Robinson in 2008, when she declared that homosexuality was an "abomination" and that it was "the government's responsibility to uphold God's law" (Curtis 141). Her words, it must be said, provoked much controversy in Northern Ireland. Would you say that homophobia has been justified in Northern Ireland on religious grounds?

JG: That is usually the case in Northern Ireland. As I said, it is still a sectarian society. Whether or not people are truly religious is beyond the point. It's like you've got your tribe, and you stick to the rules of the tribe. And you vote according to the rules of the tribe. To me, it's a very tribal society. People like Iris Robinson mention God to justify their homophobia, but they choose what issues they want to be moral about. Iris Robinson, for example, is an adulteress. ${ }^{2}$ Being unfaithful contradicts the same religious principles she uses to condemn homosexuals.

JCR: And the real tragedy, I think, is that people like Iris Robinson have gay and lesbian children who are made to suffer their hatred and narrow-mindedness. Familial homophobia, for instance, is a central issue in Snapshots. In his review, Derek Hand observes that "the adult world of family is uncomprehending of the dilemmas faced by Oisín and his friends" (68). In all your novels, there are notable generational gaps between parents and the son, who tries to evade their influence. Do you think this is a common literary trope present at any place and moment, or do you intend here to comment on the rapid cultural changes taking place in Ireland, North and South?

JG: Intergenerational conflict is a very common literary trope in Ireland and elsewhere, but it is also true that the rapid changes in Irish society particularly lend themselves to exploring this theme in fiction.

JCR: My favourite scene in Snapshots takes place when Seán finds his younger brother Oisín in the church, crying and praying not to be gay. Seán, so far ashamed of his brother's campness, tells us that Oisín "looked crushed and he was only thirteen" (156). Even if Oisín eventually accepts his sexual orientation, to what extent would you say that his Catholic upbringing affected his self-image as a gay teenager?

JG: In Northern Ireland, there is a very strong religious ethos in most schools, which affects the teaching around homosexuality. I grew up in the 1980s and 1990s, a time when it was actually illegal in schools to teach anything about homosexuality in a positive light. Being Northern Irish, you were under the rule of Margaret Thatcher, who was responsible for the infamous Section 28, which made it illegal anything that "promoted" homosexuality. This was a real, present danger for teachers who wanted to be sympathetic towards gay people. At the time there were just very little sources of knowledge other than the religious teaching on homosexuality. The Internet hadn't happened yet, so gays and lesbians were less aware of where to find information. And I would say this situation was even worse for the generations before mine.

JCR: What you say about the teachers' lack of freedom has also been a pressing concern in the Republic due to Section 37.1 (operative until 2015), whereby a Catholic school could dismiss employees if they were perceived to transgress the ethos of the institution. Many teachers avoided addressing LGBT issues in class, because it could lead to "accusations of 'undermining' the denominational ethos of the schools" (Fahie 404). Anyway, returning to the topic of your fiction, I read that, in an interview, you said that 
you did not want your novel G.A.A.Y. to be "burdened with sexual politics" (Kelly 41). There is, of course, a sense of gay affirmation when the protagonist, Anto, declares: "I refuse to turn into my parents. I refuse to breed" (42). Anto is also surrounded by a generous amount of gay friends and lovers, but it is my impression that the novel explores several issues connected with homosexual oppression as well, such as the internalised homophobia of Cathal, a G.A.A. player and Anto's closeted ex-boyfriend.

JG: G.A.A.Y. is supposed to be a romantic comedy, although the novel does draw on those social issues, mostly for comic relief. And it is my belief that you can make serious points by making people laugh. So I would like the reader to come for the story and enjoy the jokes, but I hope you pick a little bit of that political stuff. But G.A.A.Y. is definitely overtly less political than Snapshots, which is very much about politics in Northern Ireland.

JCR: I really like Anto, because even if he defines himself as a gay cliché, he is a much deeper character.

JG: I was trying to deliberately create a character who was the typical gay best friend in the romantic comedies happening at the time. I wanted to get that character a voice and an inner life, because, in all the previous incarnations, characters like that were becoming more prevalent, but they were flat and always the same type. They were there just to deliver sassy one-liners and help the girl get the right guy. And I thought, let's make it about him, he needs a boyfriend. That's why I wrote Anto the way I did.

JCR: In Snapshots and G.A.A.Y., the protagonists' open homosexuality and perceived effeminacy attract the attention of some other males who conform to traditional heteromasculinity but wish to pursue their unspoken same-sex desires. For example, in G.A.A.Y. Anto tells his gay friends that: "It might seem that I'm really into bi-curious guys, but in my defence, they're more into me" (25). But he also says that, since "he has always been seen as different" (31), it was easier for him to be openly gay. So what about those self-identified straight characters that have hidden homosexual desires? Were you trying to depict the tensions around sexuality and traditional masculinity?

JG: You mean, was it deliberate? No, I just drew on reality, stuff I've seen, people I knew. But there is also a little bit of a trope in gay literature, where your main character has to be relatable. And I think that most gay kids can identify with the "faggoty" main character, you know, the outsider. And this may be a typical narrative thread precisely because it is a quite common lived experience. What is also true is that many gay guys growing up have a crush on their straight friend. When you read a lot of gay literature - you see it in a lot of gay films - you find this cliché where there is a gay character and a closeted one, and there is a bit of romance but it usually ends tragically. I think that has become a clichéd narrative, but it felt fresh when I was writing Snapshots

JCR: What you have just said reminds me of the recent Irish film Handsome Devil (John Butler, 2016), though in this case the story avoids the sort of "tragic end" you mention.

JG: There are many kinds of "Netflixy" gay movies that have that basic premise, about a gay who is maybe out or just less traditionally masculine, who somehow picks out another gay who is more stereotypically masculine, but repressed. And you see, I believe it is just a gay fantasy, really [laughs]. And maybe that is why that theme resonates in gay fiction. 
JCR: In your novels, the paramilitary (in Snapshots), Gaelic football (in G.A.A.Y.) and the criminal world (in The Organised Criminal) emerge as sites where hegemonic heteromasculinities become contested. In my opinion, your novels deconstruct traditional notions of masculinity - the kind of rough, stoic, combative man - and expose the ways in which these masculinities become inadequate, flawed, or even damaging or repressive.

JG: I guess that, historically, many social problems came from men and the inherited notions of masculinity. Gay people have always been a challenge to those inherited notions, and it is often the case that identifying as gay means to reject old ideas of masculinity. What is relevant about characters like Oisín and Anto is that they don't want to try to conform to any ideas of masculinity. They are very queer, and their queerness helps us see the inherent contradictions and problems in the "straight" world. It is an interesting feature of gay literature that it shows the ways society operates at a certain level.

JCR: Yes, but going back to my previous question, for example, in G.A.A.Y. you queer the notion of Gaelic football, an icon of Irish masculinity, so we have Khalid, who is one of the best players, and he is English, black, Muslim and bisexual. In Snapshots, the IRA member Néil is another bisexual.

JG: I suppose that one of the ways for queerness to enter into the "heterosexual" world is through bisexuality. It is certainly a literary way of getting into the space of the traditionally masculine areas. Bisexuality, of course, also poses a challenge to the status quo in that bisexuals often move between the two socially constructed binaries of homosexuality and heterosexuality

JCR: And, then, we have Jay in The Organised Criminal. He is straight, but, from a very young age, he refuses to conform to the type of aggressive masculinity that his misogynist, xenophobic and homophobic father, Frank, represents. Jay develops close friendships with Martin, who is gay, and his female cousin, Scarlett, a battered wife whom he tries to save from her husband. It seems to me that Jay, with his sense of social justice and empathy, embodies a more open-minded and positive model of masculinity. Was it your intention?

JG: I did not try to, but it turned out that way. Jay in The Organised Criminal deliberately rejects what his father represents. Judging by the father's standards, the son is a failure and is not doing very well in life. That's a clue for the reader that Jay is just not a "dickhead" like his father. It turns out that most of what Jay does is a reaction to the father in his attempt to reject him. And, it goes without saying, the idea of "killing the father" to assert one's own independence is a sort of masculine trope that has often been explored in literature.

JCR: In the past, the straight and gay worlds were generally assumed to be totally separate and incompatible. In an article for The Irish Times, you comment that in The Organised Criminal the gay/straight friendship between Martin and Jay is "at the centre of the book" and that it represents a new time in which "being lesbian, gay, bisexual or trans is not a barrier to staying friends with straight pals" (2015). Would you say that his friendship with Martin helped Jay not to become someone like his father?

JG: It was the other way around for Jay; he didn't want to be like his father, so he became friends with Martin, the sissy boy. But their friendship blossoms at a specific moment connected with political violence in Northern Ireland. This accident opened his eyes to the 
possibility of friendship with somebody like Martin. If this had not happened, he would have never come into contact with Martin.

JCR: Does The Organised Criminal associate the deadlock of violence and criminality in the Northern Irish border to a world governed by males like Jay's father and his cohorts?

JG: That is certainly Jay's point of view. I mean, it is a piece of art not trying to solve political problems. Its aim is to reflect on characters' interpretations of political problems. But, yes, Jay sees the problem as originating from men like his father. There is a lot of organised crime in Northern Ireland, and this is no secret. Everybody knows about it! Whether or not there is any political willingness to solve this issue is a different story. Northern Ireland is still today an isolated, introverted world which has not received any international attention since the Cease Fire. It is now due to Brexit and the management of the border that discussions about Northern Ireland have reappeared. In The Organised Criminal, some of the characters' frustrations have to do with a feeling of being apart from the rest of the world. The Organised Criminal is a very Northern Irish novel. It is not a fashionable book, but I felt that someone had to tell the story.

JCR: There are not many novels dealing with the criminal organisations currently operating in the Northern Irish border, right?

JG: I dare to say that they don't get published because it is not an attractive subject. British publishers don't care; Irish publishers feel that organised crime is already an issue of the past. There are great Northern Irish novels about the Troubles or shortly afterwards, by the likes of Jennifer Johnston and Bernard MacLaverty. But I think there is plenty to examine about the legacy of it, where things are now. The Organised Criminal is a post-Troubles novel, and that is a world that gets not explored outside of journalism, and even in journalism it is largely ignored.

\section{JCR: Don't you think there is a Northern Irish readership for a post-Troubles type of novel?}

JG: No. I believe there isn't a large enough market to sustain the costs that would take for publishers to publish novels about that subject. The market isn't there, it's a small country.

JCR: What are your future plans as a fiction writer? Are you writing a novel at the moment?

JG: I have been working on a novel called Lads in Love, which is a love story set in contemporary Dublin. It's about a seventeen year-old guy who is looking for love in all the wrong places, obviously Grindr. ${ }^{3}$ His best friends are Chelsea, who is a non-lesbian butch, and Soda, who is a drag queen who often goes to Panti-Bar. And you know what, I find it really hard to get a publisher. There was a time when publishers were interested in hearing queer voices. I'm afraid that time is already over. Queer voices are regarded as being too mainstream; publishers believe queer stories are no longer edgy. All of them seem to believe that gay stories have already been done. Hopefully, I'll find a publisher who really likes it.

JCR: "Straight" stories have been done millions of times and will continue to be published. Isn't this idea that gay-themed novels are not interesting today because they 
have already been done a homophobic reaction on the part of publishers? After all, there will be future generations of gays and lesbians who would like to see their experiences reflected in fiction.

JG: I would say it's a heteronormative bias. Publishers are not necessarily thinking about future generations, they're thinking about what books will sell now. Obviously, for them, books are only business. But it's a shame that marginal voices are sidelined. I think this is a dialogue that is happening more loudly with BAME ${ }^{4}$ voices in the English-speaking world at the moment. I believe that in the publisher's mind there's an ideal reader who is straight, white, able-bodied, middle-class - and main characters can deviate from that norm in one aspect but rarely more than one. They're not allowed to be black, and working-class, and disabled, and queer. It would be seen as putting "too many issues" into one book, rather than simply reflecting the reality of that character - and lots of people - who don't fit the norm of what the publisher expects. No intersectionality, basically.

JCR: Thanks, Jarlath. I hope to see your new novel published in the near future.

\section{Notes}

${ }^{1}$ The research carried out for this interview was funded by the Autonomous Government of Galicia, Spain (Axudas Posdoutorais, ED481B 2017/042). This interview is also part of the research project FFI2017-84619-P, funded by the AEI and ERDF and the ED431D2017/17, Rede de Investigación de Lingua e Literatura Inglesa e Identidade III, Xunta de Galicia.

${ }^{2}$ See, for example, MacCambley 2014.

${ }^{3}$ A mobile dating application for gay men.

${ }^{4}$ BAME stands for "Black, Asian and Minority Ethnic Voices".

\section{Works cited}

Bird, Charlie. A Day in May: Real Lives, True Stories. Sallins: Merrion Press, 2016.

Bradley, Lara. "Gay Goings-on in Crossmaglen". The Belfast News Letter. 12 July 2001. 18.

Curtis, Jennifer. "Pride and Prejudice: Gay Rights and Religious Moderation in Belfast". The Sociological Review 61. 2 (2013): 141-159.

Fahie, Declan. “'Spectacularly Exposed and Vulnerable' - How Irish Equality Legislation Subverted the Personal and Professional Security of Lesbian, Gay and Bisexual Teachers". Sexualities 19.4 (2016): 393-411.

Ferriter, Diarmaid. Occasions of Sin: Sex and Society in Modern Ireland. London: Profile Books, 2009.

Gregory, Jarlath. Snapshots. Dublin: Sitric Books, 2001.

- G.A.A.Y.: One Hundred Ways to Love a Beautiful Loser. Dublin: Sitric Books, 2005.

- The Organised Criminal. Dublin: Liberties Press, 2015.

—. "Just Good Friends: Why a Gay/Straight Friendship is at Heart of The Organised Criminal”. The Irish Times. 5 May 2015. 20 August 2017. https://www.irishtimes.com/culture/books/just-good-friends-why-a-gay-straight-

friendship-is-at-heart-of-the-organised-criminal-1.2200621

Hand, Derek. "Snapshots by Jarlath Gregory”. Irish Times. 7 July 2001. 68.

Kelly, Shirley. "Wasn't there the Gaiety". Books Ireland 274 (2005): 41.

Leonard, Sue. “One-Sitting Reads”. Books Ireland 275 (2005): 94-95. 
MacCambley, Kirk. "Iris Robinson Affair: Five Key findings - Text Messages, Late Night Calls and Bizarre Redactions". Belfast Telegraph. 29 November 2014. 10 January 2018. https://www.belfasttelegraph.co.uk/news/northern-ireland/iris-robinson-affairfive-key-findings-text-messages-late-night-calls-and-bizarre-redactions30783514.html

Mannix-McNamara, Patricia; Emmanuel O'Grady; Eva Devaney and Didier Jourdan. "Tackling Social and Health Inequalities: Vulnerability Among the Young Lesbian, Gay and Bisexual Population in Ireland”. Psychology \& Sexuality 4.3 (2013): 268-282.

O'Higgins-Norman, James. "Straight Talking: Explorations on Homosexuality and Homophobia in Secondary Schools in Ireland". Sex Education 9.4 (2009): 381-393.

Savage, Claire. "The Organised Criminal, Jarlah Gregory". Culture Northern Ireland. 29 July $2015 . \quad 10 \quad$ September 2018. http://www.culturenorthernireland.org/features/literature/organised-criminal

Schubotz, Dirk and Malachai O'Hara. "A Shared Future? Exclusion, Stigmatization, and Mental Health of Same-Sex-Attracted Young People in Northern Ireland". Youth \& Society 43.2 (2011): 488-508.

Received: 13 March 2018 Accepted: 5 September 2018

José Carregal Romero is a post-doctoral fellow at the University of Vigo. His current research focuses on the lesbian and gay fiction of contemporary Ireland. His articles appear in journals such as Atlantis: Journal of the Spanish Association of Anglo-American Studies, PLL: Papers on Language and Literature, Critique: Studies in Contemporary Fiction, Moderna språk and Irish University Review (forthcoming). He is also writing an invited contribution on Colm Tóibín for the volume Twenty-First-Century Irish Fiction Writers in the Dictionary of Literary Biography (DLB), edited by Michael R. Molino (Southern Illinois University, USA).

jcarregal@uvigo.es 